\title{
PLANT GROWTH REGULATORS IN POPLAR CLONES DIFFERING IN RESISTANCE TO THE FUNGUS CERATOCYSTIS FIMBRIATA ELL. ET HALST
}

\author{
JADWIGA STOPIŃSKA \\ Department of Plant Physiology and Morphogenesis, \\ Institute of Biology, Copernicus University, Gagarina 9, 87-100 Toruń, Poland
}

(Received: July 27, 1993. Accepted: April 25, 1994)

\begin{abstract}
In poplar clones with different resistance to the fungus Ceratocystis fimbriata growth of shoots, intensity of transpiration and the level of endogenous growth regulators were determined. More resistant clones, Populus 'Robusta' and P. 'PK-136-2' ( $P$. nigra 'Italica': × P. laurifolia) had more intensive growth of shoots, higher water content in leaves and a lower intensity of transpiration than the more susceptible clone, $-P$. 'NE-42' $(P$. maximowiczi $\times P$. trichocarpa). The leaves of the more resistant clones contained more auxins (IAA) and cytokinins, especially zeatin, and less growth inhibitors (ABA) than those of the susceptible one. The level of plant growth regulators and/or the relations betweeen them may be responsible for the different poplar resistance to $C$. fimbriata.
\end{abstract}

KEY WORDS: resistance, poplar clones, Ceratocystis fimbriata, auxins, cytokinins, growth inhibitors

\section{INTRODUCTION}

The resistance or susceptibility of plants to fungal infection may be influenced by biotic or abiotic factors such as temperature (Bhattacharyya and Ward 1987), carbon dioxide and oxygen levels (Arnold and Rahe 1977), Fraedrich and Tainer 1989), light intensity and photoperiod (Goosens and Vendrig 1982, Kurowski and Gudmestad 1990), water (Vannini and Scarascia Mugnozza 1991) and mineral elements (Ylimartimo 1991).

The resistance of plants to various stress factors, also to fungal diseases, depends also on their anatomical features and the presence of chemical substances, such as toxic phenols and organic acidis as well as of nutrient or hormonal substances (Bidwell 1979).

There are many data which indicate that exogenously supplied growth regulators, such as auxins (Sinha and Wood 1967, Oka and Pimentel 1976), cytokinins (Edwards 1983, Liu and Bushnell 1986), the ratio of auxins to cytokinins (Haberlach et al. 1978, Kozłowska et al. 1988), abscisic acid (Ward et al. 1989, Dunn et al. 1990, Ersek et al. 1991), ethylene (Stahmann et al. 1966, Michniewicz et al. 1986) may increase or decrease the hypersensitive reaction, the degree of infection and susceptibility of tissues.

Some authors indicated that plants of different resistance or susceptibility to diseases contained also different levels of auxins (Artemenko et al. 1980, Seifers et al. 1985), cytokinins (Vizarova 1987, Vizarova et al. 1988), abscisic acid (Chigrin

\section{List of abbreviations:}

IAA - idole-3-acetic acid, NAA - 1-naphtalenacetic acid,

2,4-D - dichlorophenoxyacetic acid, ABA - abscisic acid et al. 1981). However, it must be stressed that data concerning this problem, especially in trees, are very scant.

In the investigations performed by Przybył (1984) it was found that poplar clones differed in their degree of resistance to the fungus Ceratocystis fimbriata and that the rate of the pathogen development was correlated with this feature (Przybył 1984a). The aim of the present study was to find out if poplar clones differing in their resistance to the fungus differ also in the intensity of growth, water and level of plant hormones before infection with this fungus.

\section{MATERIAL AND METHODS}

Three poplar clones were used: Populus 'NE-42' ( $P$. maximowiczi × P. trichocarpa) - susceptible clone, $P$.'PK-136-2' ( $P$. nigra 'Italica' $\times$ P. laurifolia) - moderately resistant clone, and $P$. 'Robusta-8341' - resistant clone each showing different resistance to the pathogenic fungus, Ceratocystis fimbriata.

Pieces of one-year-old shoots after the start of rhizogenesis were transferred to a growth chamber with light intensity about 6.000 lux, a 16-hour day, a temperature of $25^{\circ} \mathrm{C}$ and $50 \%$ relative humidity. The plants were cultured in Hoagland solution with Arnon microelements at $\mathrm{pH} 5.6$, diluted in the ratio 1:2. The solution was changed after 10 days. The determinations of growth parameters were performed after two months of culture for fifteen plants in each poplar clone. Other parameters measured were: fresh and dry matter of leaves and water content in these organs. The intensity of transpiration was determined by the water loss method after 24 hours in four replications with four plants in each.

In the experiment plant growth regulators, auxins, cytokinins, and growth inhibitors were also isolated. The sample contained all leaves on the shoot in each poplar clone. Plant 
hormones were extracted from the samples with $80 \%$ methanol supplemented with BHT (2, 6-di-tert-buthyl-p-cresol) the antioxidant using $10 \mathrm{mg} \mathrm{dm}^{-3}$ at $5^{\circ} \mathrm{C}$ for $48 \mathrm{hrs}$. The methanol extract was evaporated at $35^{\circ} \mathrm{C}$ to water residue. For auxins and growth inhibitors determinations water residue was adjusted to $\mathrm{pH} 3.0$ with $10 \% \mathrm{HCL}$ and extracted three times with ethyl acetate and diethyl ether. The joined organic fractions were evaporated to dry residue, washed with $0.5 \mathrm{M}$ phosphate buffer, $\mathrm{pH} 8.0$ and applied to a column $(1.0 \times 9.0 \mathrm{~cm})$ packed with Polyclar AT (polivinylpyrrolidone insoluble). The extracts were purified from phenols on columns washed out with $0.1 \mathrm{M}$ phosphate buffer, $\mathrm{pH} 8.0$ according to Gleen et al. (1972). The collected eluate was adjusted to $\mathrm{pH} 3.0$ and extracted anew with ethyl acetate and diethyl ether. The combined organic fractions were evaporated to dry residue dissolved in $96 \%$ ethanol and fractionated on a column filled with Sephadex LH-20 $(2.5 \times 30 \mathrm{~cm})$ according to Steen and Eliasson (1969). 70\% ethanol with $0.001 \mathrm{M} \mathrm{HCL}$ as the eluate was collected in $10 \mathrm{~cm}^{3}$ fractions. Fractions corresponding to the localization of synthetic IAA (Fluka) or cis-trans ABA (Sigma) were evaporated to dryness and diluted in $100 \%$ methanol.

The cytokinins were isolated and purified from the water residue after evaporating methanol according to Hewett and Wareing (1973). The water fraction was adjusted to $\mathrm{pH} 2.5$ and absorbed on an ion exchange Dowex $50 \mathrm{WX} 8 \mathrm{H}^{+}(50 / 100$ mesh) column $\left(\mathrm{v}=50 \mathrm{~cm}^{3}\right)$. The column was washed out with 1 vol. of $70 \% \mathrm{CH}_{3} \mathrm{OH}, 1.5$ vol. of $\mathrm{H}_{2} \mathrm{O}, 2$ vol. of $2 \mathrm{~N} \mathrm{NH}_{4} \mathrm{OH}$ and 5 vol. of $5 \mathrm{~N} \mathrm{NH} \mathrm{N}_{4} \mathrm{OH}$. The ammonia fractions were evaporated to dryness, dissolved in methanol and chromatographed on $\mathrm{Wh} 3 \mathrm{MM}$ paper in the solvent solution isopropanol : ammonia : water $=10: 1: 1 \mathrm{v} / \mathrm{v}$. To identify cytokinins in plant extracts zeatin (Sigma) was also chromatographed in the same solvent solution.

All plant growth regulators were analysed by biotests and by gas chromatography. The following biotests were used: for auxins - Avena section straight growth test (Audus 1959), for growth inhibitors - wheat coleoptile test (Rudnicki 1969), for cytokinins - soybean tissue test (Miller 1968).

\section{Gas chromatography} $I A A$ and $A B A$

Fractions for gas chromatography were methylated with diazomethane after Schlenk and Gellerman (1960) and injected into Chromathron GChF 18.3-4 using a glass column $(2.0 \times 0.4$ $\mathrm{cm})$ packed with Gas Chrom Q (100/120 mesh), with liquid phase $5 \%$ SE-30. The column temperature was $190^{\circ} \mathrm{C}$ with injection and detector temp. (FID) of $300^{\circ} \mathrm{C} . \mathrm{N}_{2}$ was used as carrier gas at a flow rate of $40 \mathrm{~cm}^{3} \mathrm{~min}$. As control samples IAA (Fluka) and cis-trans ABA (Sigma) were used.

\section{Zeatin and zeatin riboside}

The cytokinins were determined as described in the previous paper (Stopińska 1991).

All experiments were performed in duplicate. The results were evaluated statistically by estimating significant differences (LSD) at $\mathrm{P}=0.05$ or standard errors.

\section{RESULTS AND DISCUSSION}

The morphological characteristic of poplars and the systematic division of genus Populus were presented earlier by Bugała (1973).

The growth of poplar clones with different resistance to the fungus Ceratocystis fimbriata has been presented in Table 1. The clones $-P$. ' $P K-136-2$ ' and $P$. 'Robusta' had longer shoots with a larger number of leaves than $P$. ' $N E-42$ '. The surface area, the fresh and dry matter of leaves and the water content in these organs were also greater in the more resistant clones, especially in $P$. 'Robusta', than in the susceptible one, $P$. 'NE$42^{\prime}$. The leaves of these poplar clones differed also in transpiration intensity (Table 2). The most resistant clone, $-P$. 'Robusta', had the lowest intensity of this process. These results confirm the earlier data for poplar shoots obtained by other authors (Borejsza-Wysocki and Krzywański 1989).

TABLE 2. The intensity of transpiration of poplar clones with differing resistance to the fungus $C$. fimbriata

\begin{tabular}{lc}
\hline \multicolumn{1}{c}{ Clone } & $\begin{array}{c}\text { Intensity of transpiration } \\
\left(\mathrm{mg} / \mathrm{dm}^{2} / \mathrm{h}\right)\end{array}$ \\
\hline$P$. ' $^{\prime} \mathrm{NE}-42^{\prime}$ & $0.78 \pm 0.03$ \\
$P$. ' $^{\prime} \mathrm{PK}-136-\mathrm{2}^{\prime}$ & $0.75 \pm 0.07$ \\
$P$. 'Robusta' & $0.65 \pm 0.03^{*}$ \\
\hline
\end{tabular}

Explanations: as in Table 1.

In the leaves of the more resistant clones more auxins (IAA) and less growth inhibitors (ABA) were found than in the susceptible one, as estimated by the biological test (Figs 1,2 ) as well as by gas chromatography (Fig. 3). The data in the literature concerning this problem are very scant However, some authors indicate that auxin activity was higher in

TABLE 1. The growth of poplar clones with differing resistance to the fungus $C$. fimbriata

\begin{tabular}{|c|c|c|c|c|c|c|}
\hline \multirow[t]{2}{*}{ Clone } & \multirow{2}{*}{$\begin{array}{c}\text { Lenght } \\
\text { of shoot }(\mathrm{cm})\end{array}$} & \multirow{2}{*}{$\begin{array}{c}\text { Mean } \\
\text { number } \\
\text { of leaves }\end{array}$} & \multicolumn{4}{|c|}{ Mean per i leaf } \\
\hline & & & $\begin{array}{l}\text { Surface } \\
\left(\mathrm{dm}^{2}\right)\end{array}$ & $\begin{array}{c}\text { Fresh } \\
\text { matter }(\mathrm{g})\end{array}$ & $\begin{array}{c}\text { Dry } \\
\text { matter }(\mathrm{g})\end{array}$ & $\% \mathrm{H}_{2} \mathrm{O}$ \\
\hline P. 'NE-42' & 19.0 & 12.8 & 0.13 & $2.66 \pm 0.95$ & $0.72 \pm 0.41$ & 72.9 \\
\hline P. ' $P K-136-2$ ' & $36.6 *$ & $24.7 *$ & $0.32 *$ & $4.29 \pm 1.08$ & $1.09 \pm 0.40$ & 74.6 \\
\hline P. 'Robusta' & $25.9^{*}$ & $21.2^{*}$ & $0.46^{*}$ & $6.54 \pm 0.07$ & $1.53 \pm 0.11 *$ & 76.6 \\
\hline LSD & 2.7 & 1.4 & 0.01 & - & - & - \\
\hline
\end{tabular}




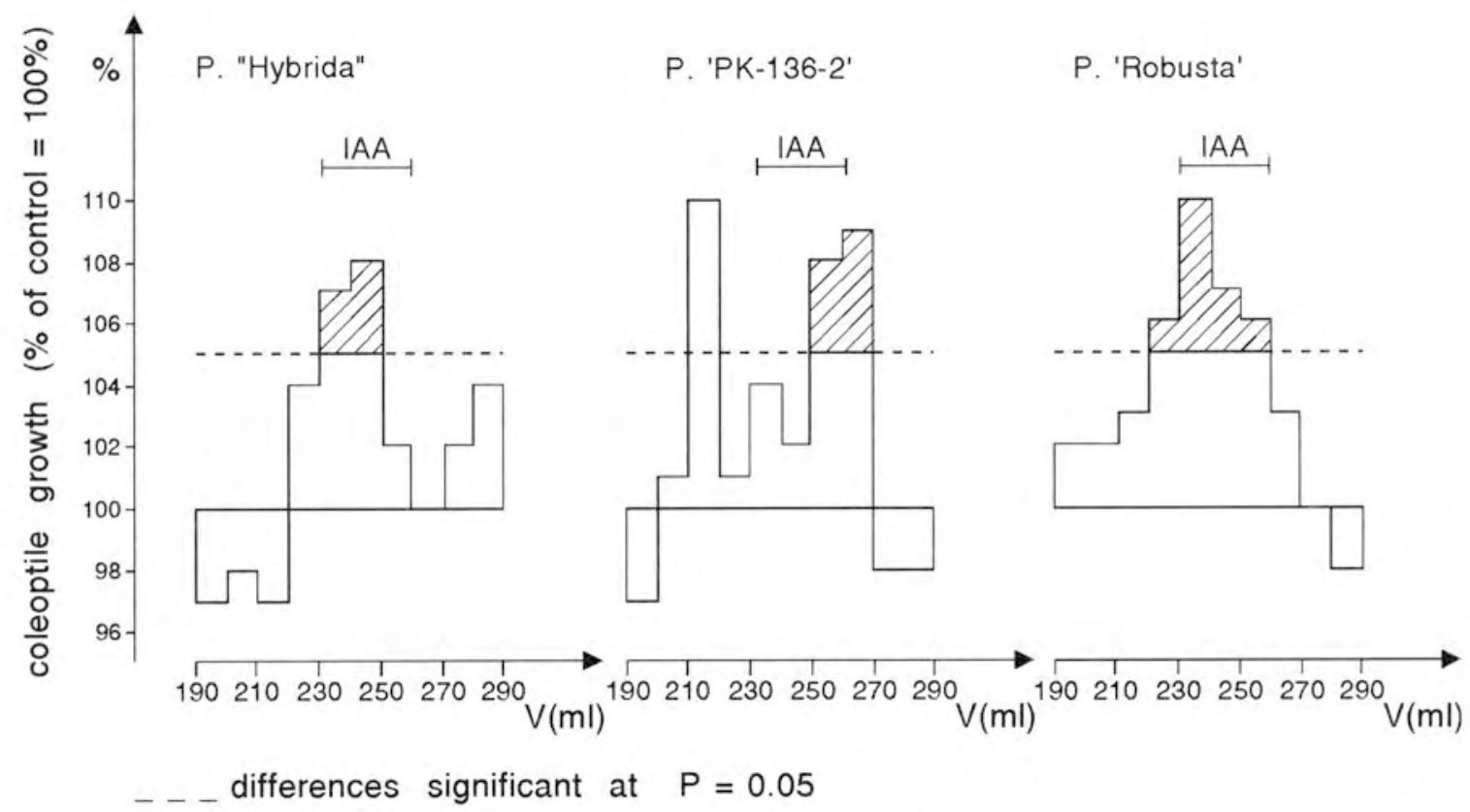

Fig. 1. Chromatographic analysis of auxins extracted from the leaves of poplar clones determined by biotest

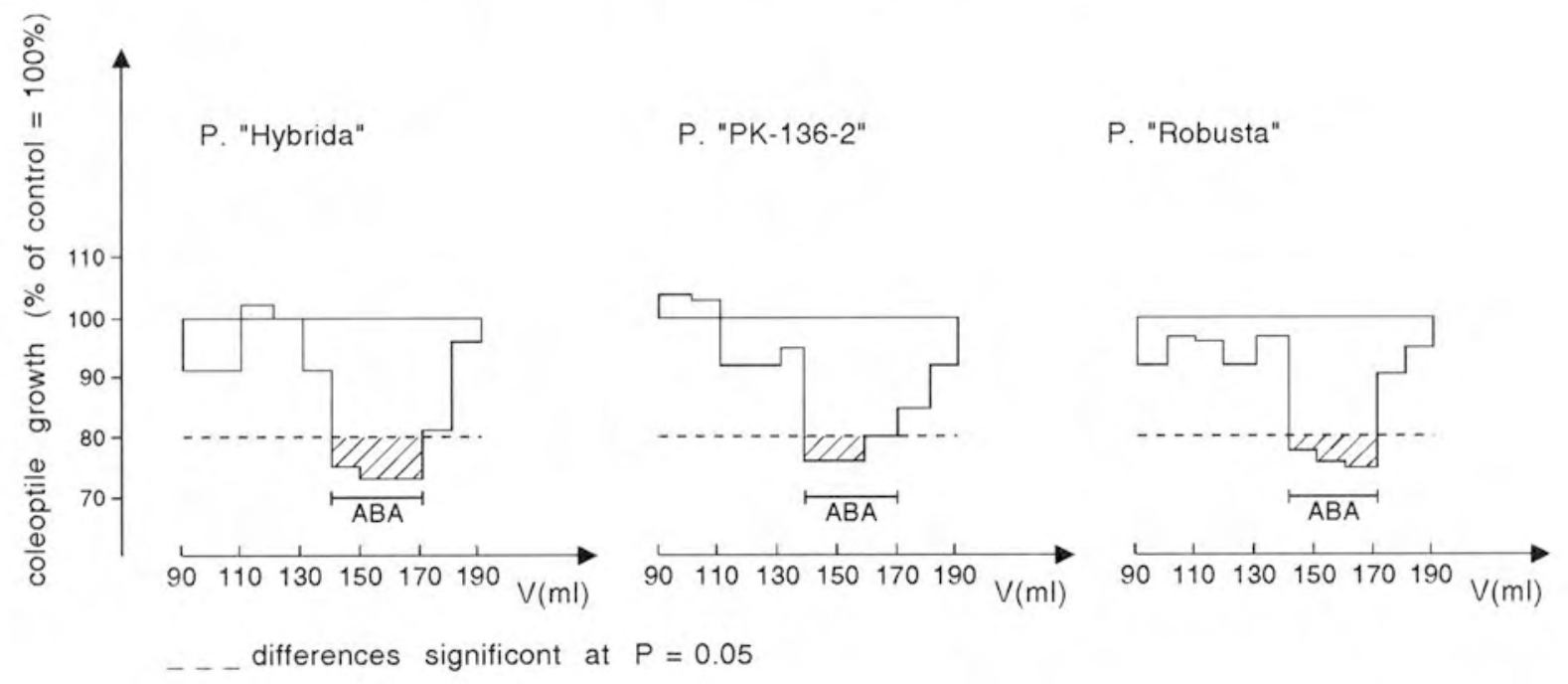

Fig. 2. Chromatographic analysis of ABA-like inhibitors extracted from the leaves of poplar clones determined by biotest
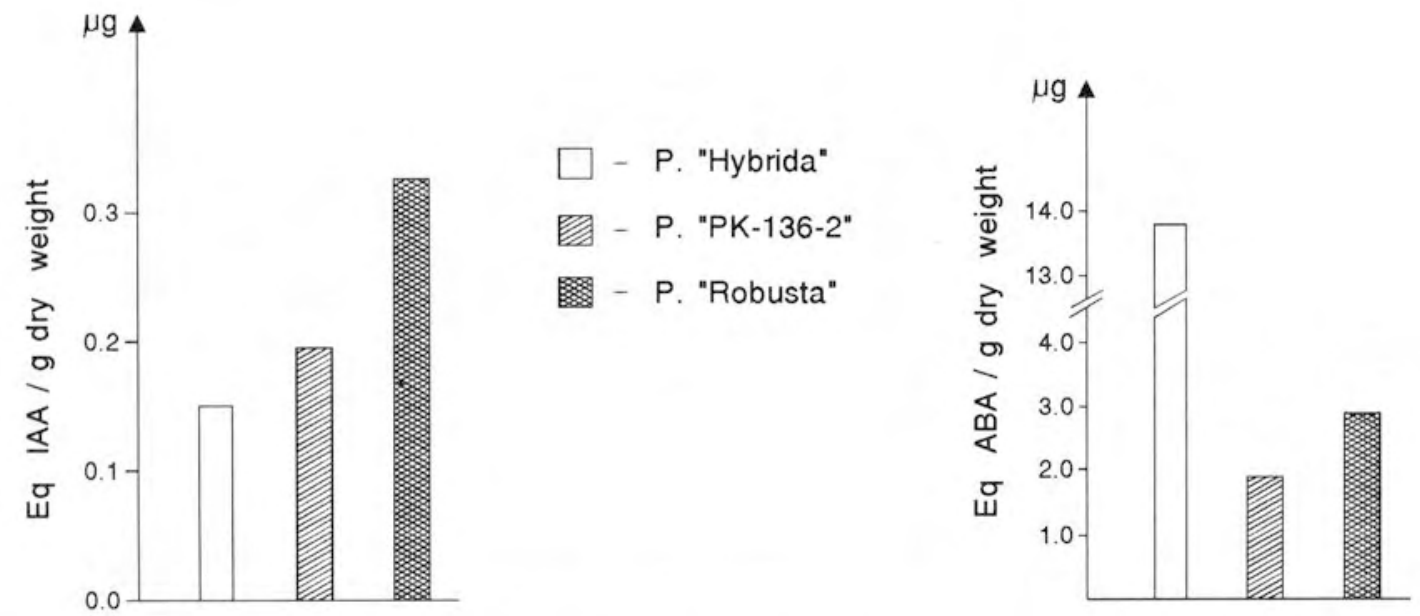

Fig. 3. Total amount of IAA and ABA in the leaves of poplar clones determined by gas chromatography 
the more resistant plant as wheat (Artemenko et al. 1980) or pine (Seifers et al. 1985) which are more resistant to the rust fungus. Contrary to these data in plants of Medicago sativa susceptible and nonsusceptible to Verticilium albo-atrum there was no difference in IAA content (Kratka and Kudela 1981). Other authors have pointed out that exogenously supplied auxins may change the susceptibility of plants to pathogens. It was found that NAA and IAA increased the resistance of tomato plants to Fusarium oxysporum (Corden and Dimond 1959) and to Verticillium wilt reducting also the fungus growth (Sinha and Wood 1967). 2, 4-D also increased the resistance of Arachis hypogea to Phythium myriotylum (Sinha and Wood 1967). According to Pegg (1976) the influence of auxins may be indirect through the stimulation of ethylene production, a very important factor in plant resistance reactions. It was found that more resistant poplar clones produced more ethylene than susceptible ones (Stopińska, unpublished data), which strongly inhibited the growth and development of C. fimbriata (Stopińska and Kuik 1991).

In this study the IAA to ABA ratio was found to be inverse. In the more resistant clones there was less $\mathrm{ABA}$ in leaves than in the susceptible plants. The high susceptibility of $P$. ' $N E-42$ ' to $C$. fimbriata may be associated with the stimulative effect of $\mathrm{ABA}$ on the growth and spore germination process of this pathogen (Stopińska and Michniewicz 1988). The same relationship in the content of ABA was found in wheat plants with different resistance to Puccinia graminis (Chigrin et al. 1981). Dunn et al. (1990), however, found that physiologically induced resistance of Phaseolus vulgaris to a compatible race of Colletotrichum lindemuthianum was associated with increases in ABA content. Many workers underlined that exogenous treatment with abscisic acid increased the plant susceptibility e.g. of barley to Erysiphe graminin (Edwards 1983), of tobacco to Peronospora tabacina (Salt et al. 1986), or of soybeans to Phytophtora megasperma (Ward et al. 1989). Ersek et al. (1991) found that ABA inhibited the hypersensitive necrosis of potato tubers to elicitor from Phytophtora infestans but Henfling et al. (1980) demonstrated that potato tissues became susceptible to a noncompatible race of Cladosporium cucumber pathogen after ABA treatment. The studies of Henfling et al. suggest that ABA affects directly the plant reaction to pathogen, and not through the pathogen or its interaction with the host. The data obtained by Michniewicz et al. (1990) indicated that ABA stimulated disease development in wheat seedlings, and this reaction was associated with a decrease in ethylene level in leaves.

The level of cytokinins in poplar plants differing in resistance to $C$. fimbriata has been presented in Figures 4-7. The more resistant clones, $-P$. ' $P K-136-2$ ' and $P$. 'Robusta', contained also much larger total amounts of cytokinins, especially zeatin, in leaves, which was detected by the biological test (Fig. 4) as well as by gas chromatography (Figs 5, 7). No zeatin riboside was found in these organs (Fig. 6). Among seven cytokinins detected in mature leaves of $P$. 'Robusta' by Hewett and Wareing (1973) there were also two identified as zeatin and zeatin riboside-like cytokinins. A close correlation between the content of cytokinins and the resistance of plants to pathogens was found by other authors. Cultivars of wheat and barley more resistant to mildew contained also more cytokinins in the seeds (Vizarova and Vozar 1984) and leaves

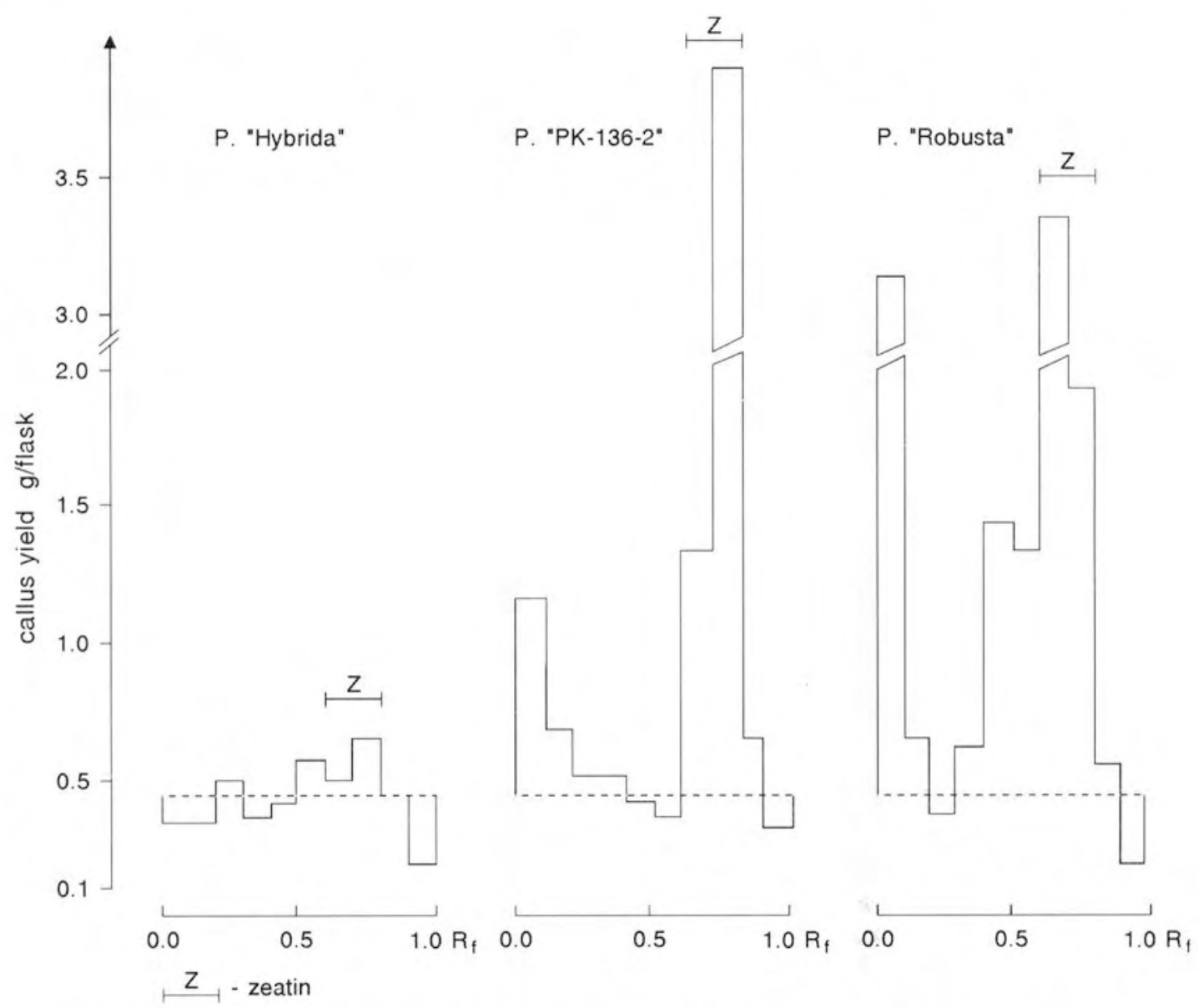

Fig. 4. Chromatographic analysis of cytokinins extracted from the leaves of poplar clones determined by biotest 


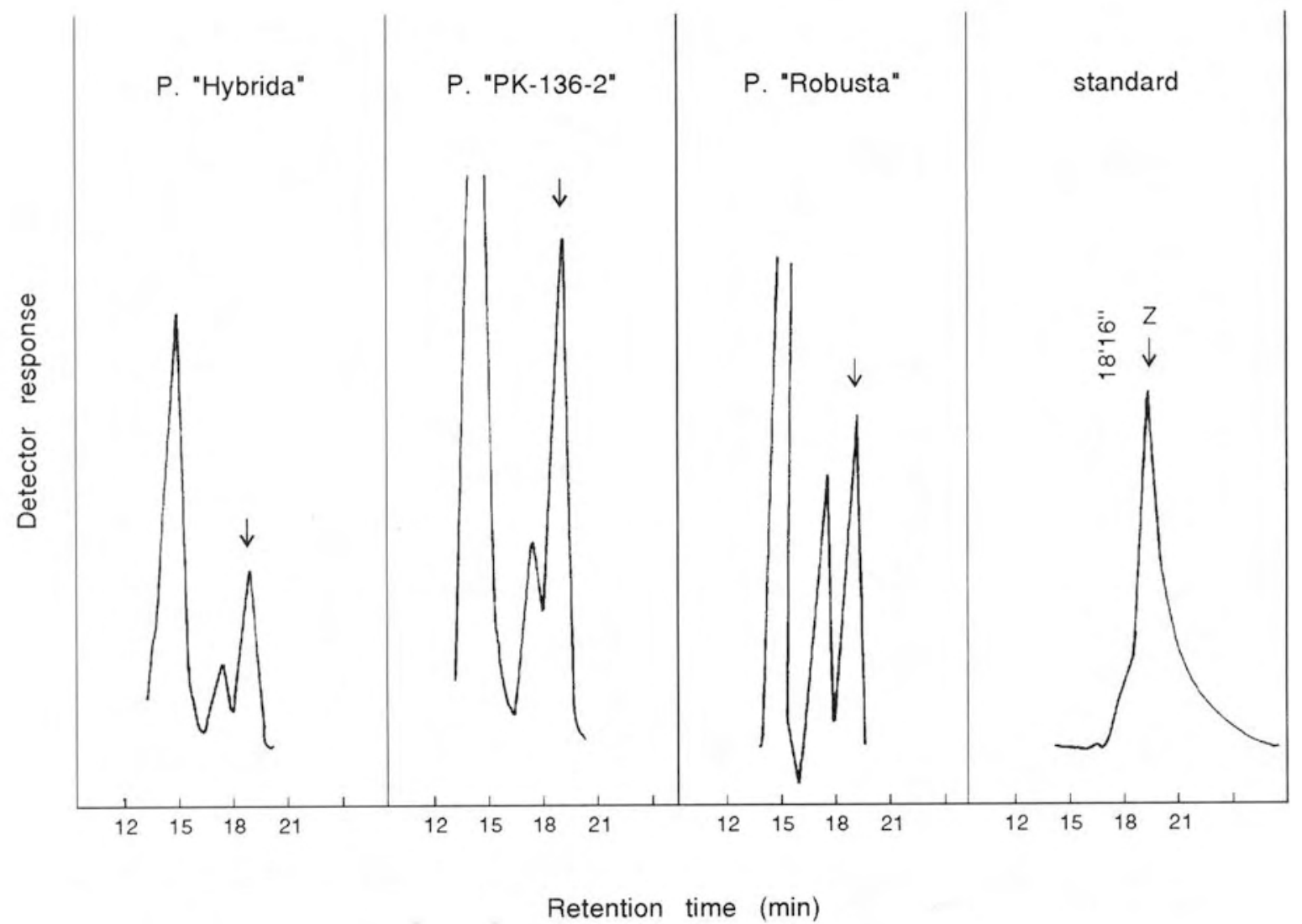

Fig. 5. Gas chromatography analysis of zeatin extracted from the leaves of poplar clones

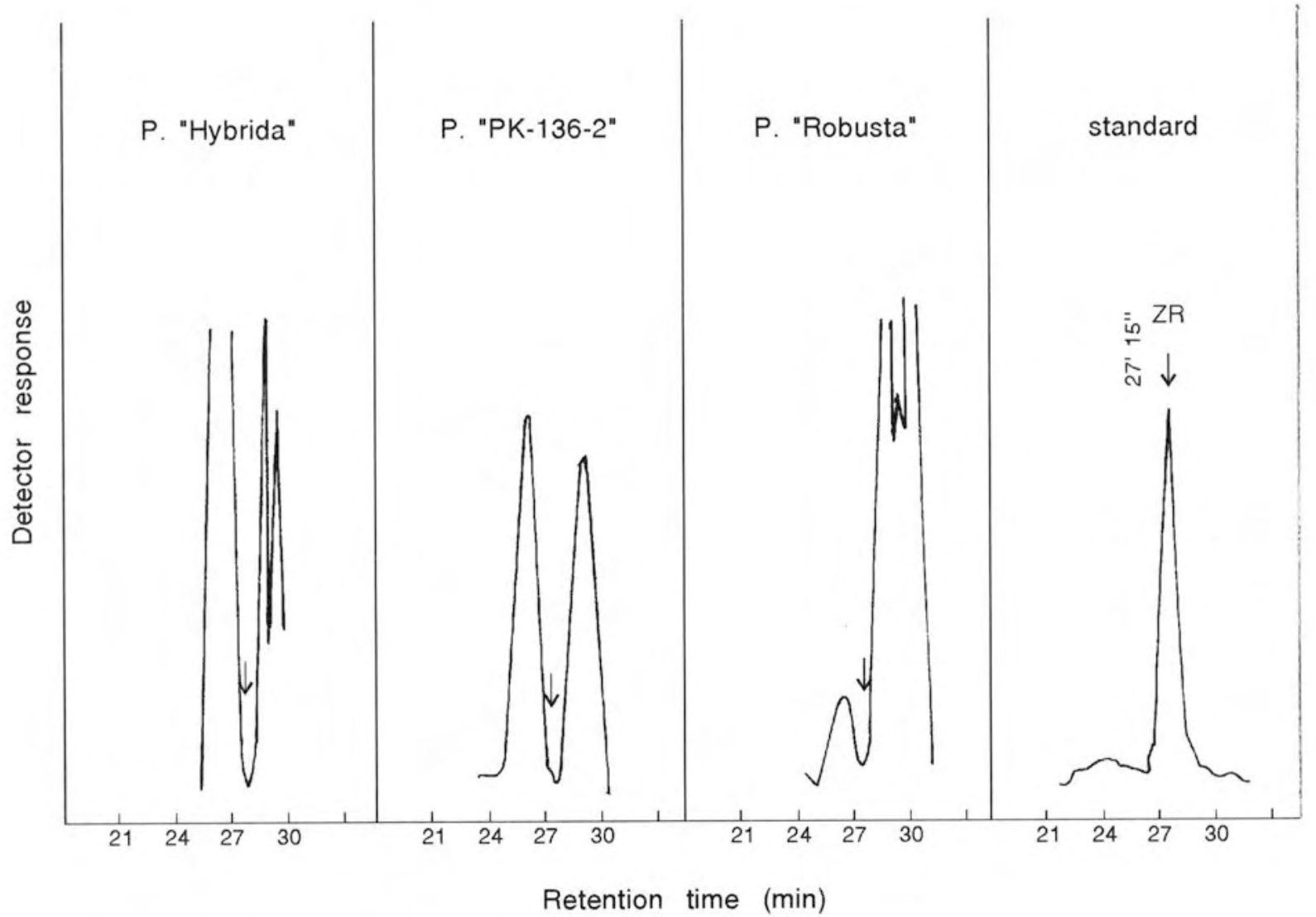

Fig. 6. Gas chromatography analysis of zeatin riboside extracted from the leaves of poplar clones 


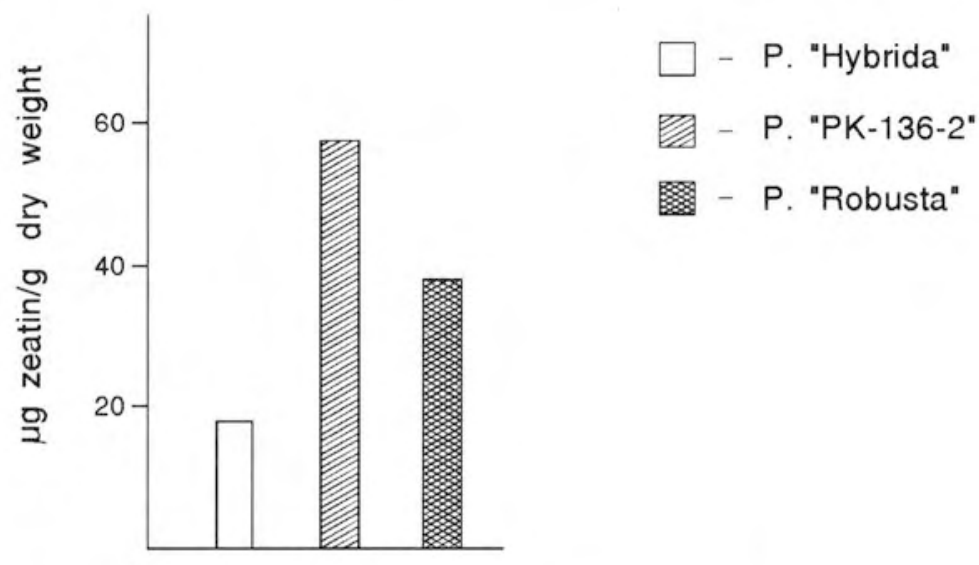

Fig. 7. Total amount of zeatin in the leaves of poplar clones determined by gas chromatography

(Vizarova 1987). Cultivars of wheat and barley resistant to mildew (Vizarova 1987) and to stem rust (Vizarova et al. 1988) contained also higher lavels of free zeatin and its derivatives during the whole ontogeny than susceptible plants. These results suggesting the importance of cytokinin viz. of free zeatin, for the plant's resistance to fungi are supported by the results of experiments in which zeatin strongly inhibited the growth of Erysiphe graminis (Vizarova 1987) or the sporulation and spore germination processes of $C$. fimbriata (Stopińska 1991). The role of cytokinins in plant resistance is also presented in papers concerning the treatment with exogenous cytokinins. It was found that kinetin increased the resistance of barley (Edwards 1983) and red raspberry callus tissue (Kozłowska et al. 1988) to fungi. Some authors indicated that cytokinins induced hypersensitive reaction of plants (Liu and Bushnell 1986), others, however, claimed that it eliminated this reaction (Haberlach et al. 1978). Kozłowska et al. (1988) suggested that plant susceptibility depended upon the ratio of auxins to cytokinins in the medium.

Taking all of these into consideration, the level of plant growth regulators and/or the relations between them may be responsible for different poplar resistance to $C$. fimbriata.

\section{ACKNOWLEDGEMENT}

The poplar cuttings had been kindly provided by Professor R. Siwecki from the Institute of Dendrology PAN in Kórnik.

\section{LITERATURE CITED}

ARNOLD R. M., RAHE J. E., 1977. Effects of $15 \% \mathrm{CO}_{2}$ on accumulation of the phytoalexin phaseollin in Phaseolus vulgaris in response to mechanical injury and to infection by Colletotrichum lindemuthianum. Can. J. Bot. 55: 867-871.

ARTEMENKO E. N., UMNOV A. M., CHKANIKOV D. I., 1980. Changes and possible ways of regulation of indole-3-acetic acid level in laeves of wheat infected with stem rust. Plant Physiol. (in Russian) 27: 592-598.

AUDUS L. J., 1959. Plant Growth Substances. Leonard Hill, London: 49-97.

BHATTACHARYYA M. K., WARD E. W. B., 1987. Temperature-induced susceptibility of soybeans to Phytophtora megasperma f. sp. glycinea: phenylalanine ammmonia-lyase and glyceollin in the host; growth and glyceollin I sensitivity of the pathogen. Physiol. Mol. Plant Pathol. 31: 407-419.
BIDWELL R. G. S., 1979. Parasites and Disease. Plant Physiology. Macmillan Publishing Co. Inc., New York.

BOREJSZA-WYSOCKI W., KRZYWAŃSKI Z., 1989. Electrolyte content and traspiration rate of poplar shoots infected by Ceratocystis fimbriata. P. T. P. N. Prace Komisji Nauk Roln. i Komisji Nauk Leśnych 67: 3-9.

BUGAŁA W., 1973. Systematyka i zmienność. In: Nasze drzewa leśne. Monografie popularnonaukowe. Tom XII. Topole. Populus L. PWN, Warszawa - Poznań.

CHIGRIN V. V., ZHIGALKINA T. E., YUKNOV A. I., SAUTICH M. A., 1981. Abscisic acid in wheat leaves infected with stem rust fungus. Plant Physiol. (in Russian) 28: 58-65.

CORDEN M. E., DIMOND A. F., 1959. The effect of growth-regulating substances on disease resistance and plant growth. Phytopathology 49: 68-72.

DUNN R. M., HEDDEN P., BAILEY J. A., 1990. A physiology-induced resistance of Phaseolus vulgaris to a compatible race of Colletotrichum lindemuthianum is associated with increases in ABA content. Physiol. Mol. PLant Pathol. 36: 339-349.

EDWARDS H. H., 1983. Effects of kinetin, abscisic acid and cations on host-parasite relations of barley inoculated with Erysiphe graminis f. sp. hordei. Phytopathol. Z. 107: 22-30.

ERSEK T., LADYZHENSKAYA E. P., KORABLEVA N. P., ADAM A., 1991. Abscisic acid and reverses the arachidonic acid-induced inhibition of plasma membrane-bound ATP-ase. J. Phytopathology 132: $146-152$.

FRAEDRICH S. W., TAINTER F. H., 1989. Effect of dissolved oxygen concentration on the relative susceptibility of shortleaf and loblolly pine root tips to Phytophora cinnamomi. Phytopatology 79: 1114-1118.

GLEEN J. L., KUO C. C., DURLEY R.C., PHARIS R. P., 1972. Use of insoluble polyvinylpyrrolidone for purification of plant extracts and chromatography of plant hormones Phytochemistry 11: 345351 .

GOOSENS J. F. V., VENDRIG J. C., 1982. Effects of abscisic acid, cytokinins and light on isoflavonoid phytoalexin accumulation in Phaseolus vulgaris L. Planta 154: 441-446.

HABERLACH G., BUDDE A. D., SEQUEIRA, HELGESON J. P., 1978. Modification of disease resistance of tobacco callus tissues by cytokinins. Plant Physiol. 62: 522-525.

HENFLING J. W. D. M., BOSTOCK R., KUĆ J., 1980. Effect of abscisic acid on rishitin and lubimin accumulation and resistance to Phytophtora infestans and Cladosporium cucumerinum in potato tuber tissue slices. Phytopathology 70: 1074-1078.

HEWETT E. W., WAREING P. F., 1973. Cytokinins in Populus $x$ robusta changes during chilling and budburst. Physiol. Plant. 28: 393-399.

KOZŁOWSKA M., KRZYWAŃSKI Z., TASZEK U., 1988. Effect of 2,4-D and benzyladenine on colonization of red raspberry callus tisue with Didymella applanata (Niessl) Sacc. and on accumulation of phenolics. Acta Physiol. Plantarum 10: 25-30. 
KRATKA J., KUDELA V., 1981. Biochemical changes in alfalfa plants inoculated with Verticillium albo-atrum. Phytopath. Z. 100: 289-299.

KUROWSKI CH. J., GUDMESTAD N. C., 1990. The effect of ethylene and abscisic acid on symptom expression of bacterial ring rot in eggplant and potato. Amer. Potato Journal 67: 443-459.

LIU Z., BUSHNELL W. R., 1986. Effects of cytokinins on fungus development and host response in powdery mildew of barley. Physiol. Mol. Plant Pathol. 29: 41-52.

MICHNIEWICZ M., ROŻEJ B., CZERWIŃSKA E., KRUSZKA G., 1986. Effect of Ethrel treatment of wheat on the susceptibility to fungal diseases and on the root zone mycoflora of this plant. Acta Agrobot. 39: 15-22.

MICHNIEWICZ M., CZERWIŃSKA E., ROŻEJ B., 1990. Interaction of abscisic acid and ethylene in relation to disease development in wheat seedlings infected by Fusarium culmorum (W. G. Sm) Sacc. Acta Physiol. Plant. 12: 41-48.

MILLER C. O., 1968. Naturally-occuring cytokinins. In: Biochemistry and Physiology of Plant Growth Substances. F. Wightman, G. Setterfield (eds.) Runge Press, Ottawa: 33-45.

OKA I. N., PIMENTEL D., 1976. Herbicyde (2,4-D) increases insect and pathogen pests on corn. Science 193: 239-240.

PEGG G. F., 1976. Endogenous auxins in healthy and diseased plants. In: Physiol. Pant Pathology. Encyclop. Plant Physiol. N.S.4. R. Heitefuss, P. H. Williams (eds.) Springer-Verlag, Berlin - Heidelberg New York: 560-581.

PRZYBYŁ K., 1984. Disease of poplar caused by Ceratocystis fimbriata Ell. et Halst. I. Isolation of $C$. fimbriata, symptoms of the disease and evaluation of resistance of poplar clones resulting from artificial infection. Arboretum Kórnickie 29: 89-103.

PRZYBYŁ K., 1984a. Development of the fungus Ceratocystis fimbriata in shoots of poplar clones with differing resistance. Sonderdruck Eur. J. For. Pathol. 14: 177-183.

RUDNICKI R., 1969. Studies on abscisic acid in apple seeds. Planta 86: 63-68.

SALT S. D., TUZUN S., KUĆ J., 19986. Effects of B-ionone and abscisic acid on the growth of tobacco and resistance to blu mold. Mimicry of effects of stem infection by Peronospora tabacina Adam. Physiol. Mol. Plant Pathol. 28: 287-297.
SCHLENK H., GELLERMAN J. L., 1960. Estrification of fatty acids with diazomethane on small scale. Analitical Chemistry 32: 1412-1414.

SEIFERS D., AMMON V., SPENCER J., 1985. Alteration in auxin levels in selected southern pines inoculated with the fusiform rust fungus. Agric. Ecosystem and Environment 14: 131-138.

SINHA A. K., WOOD R. K. S., 1967. The effect of growth substances on Verticillium wilt of tomatao plants. Ann. Appl. Biol. 59: 117-128.

STAHMANN M. A., CLARE B. G., WOODBURY W., 1966. Increased desease and enzyme activity induced by ethylene production by black rot-infected sweet potato tissue. Plant Physiol. 41: 1505-1512.

STEEN I., ELIASON L., 1969. Separation of growth regulators form Picea abies Karst. on Sephadex LH-20. J. Chromatogr. 43: 558-560.

STOPIŃSKA J., 1991. Control of growth and development of Ceratocystis fimbriata Ell. et Halst. by growth regulators. III. Cytokinins. Bull. Pol. Acad. Sci., Ser. biol. 39: 281-289.

STOPIŃSKA J., KUIK K., 1991. IV. Ethylene. Ibid 39:291-300.

STOPIŃSKA J., MICHNIEWICZ M., 1988. II. Abscisic acid. Ibid 36: 259-264.

WARD E. W. B., CAHILL D. M., BHATTACHARYYA M. K., 1989. Early cytological differences between compatible and incompatible interactions of soybean with Phytophtora megasperma f. sp. glycinea. Physiol. Mol. Plant Pathol. 34: 267-283.

VANNINI A., SCARASCIA MUGNOZZA G., 1991. Water stress: a predisposing factor in the pathogenesis of Hypoxylon mediterraneum on Querus cerris. J. For. Pathol. 21: 193-201.

VIZAROVA G., 1987. Possible role of cytokinins in cereals with regard to the resistance to obligate fungus parasites. Biol. Plant. (Praha) 29: 230-233.

VIZAROVA G., SHASHKOVA L. S., 'ANDREEV L. N., 1988. On the question of the relationship between free zeatin content and resistance of wheat to biotrophic fungi. Acta Phytopathol. Entomol. Hungarica 23: 385-392.

VIZAROVA G., VOZAR I., 1984. Free endogenous cytokinin content in the seeds of barley and wheat cultivars with different resistance to powdery mildew. Biochem. Physiol. Pflanzen 179: 767-774.

YLIMARTIMO A., 1991. Effects of foliar nitrogen, potassium and magnesium concentrations on the resistance of Scots pine seedlings to Scleroderris cancer infection, Europ. J. For. Pathol. 21: 414-423.

\section{REGULATORY WZROSTU W KLONACH TOPOLI O RÓŻNEJ ODPORNOŚCI NA GRZYB CERATOCYSTIS FIMBRIATA ELL. ET HALST.}

\section{STRESZCZENIE}

W klonach topoli o różnej odporności na grzyb Ceratocystis fimbriata oznaczono wzrost pędów, intensywność transpiracji i poziom endogennych regulatorów wzrostu. bardziej odporne klony, $P$. ' $P K-136-2$ ' i $P$. 'Robusta', cechowały się intensywniejszym wzrostem pędów, wyższą zawartością wody w liściach i niższą intensywnością transpiracji niż klon bardziej wrażliwy - $P$. 'NE-42'. Liście bardziej odpornych klonów zawierały więcej auksyn (IAA) i cytokinin, szczególnie zeatyny a mniej inhibitorów wzrostu (ABA) niż liście klonu wrażliwego. Poziom regulatorów wzrostu i/lub zależności pomiędzy nimi mogą stanowić o różnej odporności topoli na $C$. fimbriata.

SŁOWA KLUCZOWE: odporność, klony topolii, Ceratocystis fimbriata, auksyny, cytokininy, inhibitory wzrostu. 